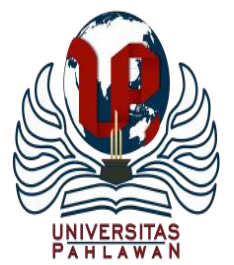

Edukatif : Jurnal Ilmu Pendidikan Volume 3 Nomor 4 Tahun 2021 Halm 1974 - 1984

EDUKATIF: JURNAL ILMU PENDIDIKAN

Research \& Learning in Education

https://edukatif.org/index.php/edukatif/index

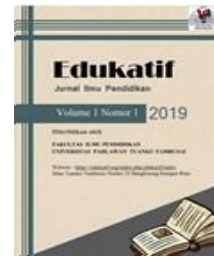

\title{
Pengaruh Kepercayaan Diri dan Motivasi Belajar terhadap Kemampuan Berpikir Kritis pada Siswa Sekolah Dasar
}

\author{
Siti Ambarwati ${ }^{1 凶}$, Suhartono $^{2}$, Nurhasanah ${ }^{3}$ \\ Universitas Terbuka, Indonesia ${ }^{1},^{3}$ \\ Universitas Sebelas Maret, Indonesia ${ }^{2}$ \\ E-mail : sitiambarwati85@gmail.com ${ }^{1}, \underline{\text { suhartono @ fkip.uns.ac.id }}^{2}, \underline{\text { nenganah@ecampus.ut.ac.id }}{ }^{3}$
}

\begin{abstract}
Abstrak
Kemampuan berpikir kritis merupakan salah satu kompetensi yang harus dikuasai siswa pada abad 21 untuk menghadapi tantangan di masa depan. Penelitian ini bertujuan untuk mengetahui pengaruh kepercayaan diri dan motivasi belajar terhadap kemampuan berpikir kritis pada siswa kelas V sekolah dasar se-Kecamatan Ambal dengan pendekatan kuantitatif dengan jenis penelitian regresi, pengambilan sampel menggunakan simple random sampling, dan pengumpulan data dengan angket dan tes. Teknik analisis data dengan uji asumsi klasik dan uji regresi ganda dengan menggunakan SPSS 25. Berdasarkan analisis data diperoleh kesimpulan sebagai berikut: (1) Ada pengaruh kepercayaan diri terhadap kemampuan berpikir kritis sebesar 25\%, dengan nilai Sig = 0,000. (2) Ada pengaruh motivasi belajar berpengaruh terhadap kemampuan berpikir kritis sebesar 11,5\% dengan nilai Sig $=0,000$. (3) Ada pengaruh kepercayaan diri dan motivasi belajar terhadap kemampuan berpikir kritis sebesar 87\%, sedangkan sisanya diengaruhi oleh faktor-faktor lain di luar model penelitian ini. Hal ini membuktikan bahwa ada pengaruh yang kuat antara kepercayaan diri, motivasi belajar, dan kemampuan berpikir kritis siswa.
\end{abstract}

Kata Kunci: kepercayaan diri; motivasi belajar; kemampuan berpikir kritis.

\section{Abstract}

Critical thingking skills is one of the competencies that students must have in the $21^{\text {st }}$ century to confront the future challenges.This research is aims to determine wheter the self confidence and learning motivation on the the critical thingking skills of the fifth grade students in Ambal District with a quantitative approach with regression research thype, the sampiling using simple random sampling, and the data collection technique use was questionnaires and test. Data were analyzed by classic assumption test and multiple regressions using Special Package for Statistic Science (SPSS) 25. Based on the data analysis the concluded is: (1) There is effect self confidence on the critical thing skills amounting to $25 \%$ with a significance value 0,000. (2) There is effect learning motivation on the critical thingking skills amounting to 11,5\% with a significance value 0,000. (3) Ther are effect self confidence and learning motivation on the critical thingking skills amounted to $87 \%$, while the rest $13 \%$ influenced by other factors outside the model in this study.

Keywords: self confidence; learning motivation; critical thingking skills.

Copyright (c) 2021 Siti Ambarwati, Suhartono, Nurhasanah

$\triangle$ Corresponding author

Email : sitiambarwati85@ gmail.com

DOI : https://doi.org/10.31004/edukatif.v3i4.1047

ISSN 2656-8063 (Media Cetak)

ISSN 2656-8071 (Media Online) 
1975 Pengaruh Kepercayaan Diri dan Motivasi Belajar terhadap Kemampuan Berpikir Kritis pada Siswa Sekolah Dasar - Siti Ambarwati, Suhartono, Nurhasanah

DOI: https://doi.org/10.31004/edukatif.v3i4.1047

\section{PENDAHULUAN}

Tantangan pembelajaran di abad 21 memuntut siswa untuk memiliki kemampuan dalam bidang keilmuan, keterampilan metakognitif, berpikir kritis dan kreatif, serta berkomunikasi atau berkolaborasi secara efektif (Sugiyarti et al., 2018). Siswa harus memiliki empat kompetensi tantangan di abad ke-21 dikenal dengan 4C yaitu berkomunikasi, berkolaborasi, berpikir kritis, dan memecahkan masalah (Pangestu et al., 2019). Dengan demikian, salah satu kemampuan penting yang harus dimiliki oleh siswa adalah kemampuan berpikir kritis.

Keterampilan berpikir kritis siswa Indonesia masih tergolong rendah. Berdasarkan penelitian TIMSS (Trends in International Mathematics and Science Study) pada tahun 2015 menunjukkan bahwa siswa Indonesia memperoleh peringkat skor Matematika nomor 44 dari 49 negara, sedangkan skor IPA berada pada peringkat 46 dari 49 negara (Nizam, 2016). Kenyataan yang terjadi di lapangan, siswa kurang bisa memahami pelajaran Sejarah, Biologi, Ilmu Sosial, atau Matematika apabila membaca dengan kritis tidak mereka lakukan. Proses berpikir yang dialami siswa memiliki peran penting untuk kesehatan mental, prestasi yang tinggi, dan kesuksesan profesional. Dengan dimikian, siswa harus senantiasa didorong agar mampu memberikan pendapat tentang apa yang mereka baca menganalisis bahan, membentuk ide-ide yang kreatif, mengevaluasi, membandingkan, dan membedakan pilihan yang berbeda berhubungan pada apa yang telah dibaca dengan menghubungkan pengalaman yang pernah dialami (Assaly \& Smadi, 2015).

Kemampuan berpikir kritis merupakan kemampuan yang dimiliki oleh seseorang dalam proses berpikir dengan pertimbangan secara cermat melalui berbagai sumber dalam meberikan keputusan secara tepat dan matang. Kemampuan berpikir kritis seseorang merupakan "essential core life skills" yang harus dimiliki oleh setiap individu . Berpikir kritis menjadi dasar keterampilan hidup sehingga harus senantiasa dilatih dan diasah. Fachrurazi (2011) menjelaskan kemampuan berpikir kritis merupakan proses yang sistematis memberikan kesempatan dalam merumuskan dan mengevaluasi keyakinan dan pendapat siswa. Tahap merumuskan, mengevaluasi keyakinan, dan pendapat siswa diperlukan diperlukan kepercayaan diri agar siswa dapat memahami, menerima, serta menilai kekurangan dan kelebihan dalam diri agar tujuan pembelajaran dapat tercapai. Salah satu kesulitan yang masih dialami siswa yaitu penerapan kemampuan dalam berpikir kritis.

Berdasarkan perkembangan teori kognitif Piaget, karakteristik siswa kelas V berada pada tahap operasional konkret (usia 7-8 s/d 12-14 tahun) yang memiliki karakteristik perilaku impulsif mulai diganti dengan refleksi dasar dan anak mulai dapat membedakan perbedaan pandangan orang lain, termasuk cara berpikir logis terkait dengan objek (Suciati et al., 2014).

Melalui berpikir kritis, siswa berpikir dengan lebih luas dan penuh dengan tantangan. Berpikir kritis diterjemahkan sebagai sesuatu yang memungkinkan seseorang dalam memberikan kepastian melalui alasan yang kuat untuk percaya tentang apa yang telah diyakini atau lakukan benar (Bowell \& Kemp, 2005). Berpikir kritis (critical thingking) didefinisikan oleh Dewey sebagai sikap aktif, gigih, melalui pertimbangan yang cermat dipandang dari berbagai sudut alasan yang didukung dan disimpulkan mengenai sebuah keyakinan atau bentuk pengetahuan apapun yang diterima seorang individu (Surya, 2011). Melalui pertimbangan yang cermat, para pemikir kritis akan menunjukkan keinginan atau motivasi dan semangat dalam menemukan jawaban atas permasalahan apakah sudah sesuai dan masuk akal atau belum. Dengan demikian, berdasarkan beberapa pendapat tersebut diperoleh kesimpulan bahwa kemampuan berpikir kritis (critical thingking) sebagai salah satu kemampuan berpikir tingkat tinggi yang sangat esensial untuk kehidupan sebagai proses mental yang dialami individu dalam menganalisis dan atau mengevaluasi melalui pemahaman secara mendalam untuk menemukan jawaban yang benar atas permasalahan melalui pertimbangan yang cermat.

Hasil observasi menunjukkan beberapa permasalahan yang dialami siswa yaitu: 1) Sebagian besar siswa belum berani mengungkapkan pendapat tentang topik permasalahan yang diajukan oleh guru, 2) banyak siswa tidak menunjukkan minatnya dalam belajar, 3) kebanyakan siswa hanya mengandalkan siswa lain yang unggul 
1976 Pengaruh Kepercayaan Diri dan Motivasi Belajar terhadap Kemampuan Berpikir Kritis pada Siswa Sekolah Dasar - Siti Ambarwati, Suhartono, Nurhasanah

DOI: https://doi.org/10.31004/edukatif.v3i4.1047

di kelas dalam mengerjakan tugas, 4) siswa terlihat kesulitan dan membutuhkan waktu yang lama dalam mengerjakan soal, 5) banyak siswa masih mengalami kesulitan berkaitan pada pengungkapan pendapat secara kritis, dan 6) siswa enggan bertanya kepada guru walaupun sudah diberikan kesempatan bertanya karena malu. Kondisi berbeda ditunjukkan ketika guru memberikan perhargaan berupa tepuk tangan dan pujian, banyak siswa yang mulai menjawab dan bertanya berkaitan dengan materi berkaitan dengan permasalahan yang diajukan. Berdasarkan penjelasan yang telah diungkapkan sebelumnya dapat disimpulkan bahwa motivasi belajar dan kepercayaan diri siswa di Kecamatan Ambal masih tergolong rendah. Uraian permasalahan tersebut mengindikasikan bahwa kepercayaan diri dan motivasi belajar memberikan pengaruh terhadap kemampuan berpikir kritis siswa. Kepercayaan diri dan motivasi belajar memiliki hubungan yang erat dengan kemampuan berpikir kritis siswa yang mendukung perkembangan dirinya di masa depan.

Penilaian pada diri berkaitan pada penilaian yang positif. Melalui penilaian yang positif pada diri seorang individu akan memicu tumbuhnya motivasi untuk lebih mau menghargai apa yang ada dalam diri sebagai karunia yang diberikan Tuhan YME. Penilaian positif merupakan keyakinan yang dimiliki oleh seseorang terhadap kelebihan yang dimiliki sehingga membuatnya merasa berbagai tujuan hidup dapat dicapai (Hakim, 2005). Fatimah (2006) menjelaskan kepercayaan diri sebagai sifat positif seseorang sehingga membuat dirinya mampu untuk melakukan penilaian secara positif terhadap diri maupun lingkungan, juga situasi yang ia hadapi. Setiawan (2014) menjelaskan kepercayaan diri adalah kondisi mental atau psikologis individu, dimana ia dapat melakukan penilaian diri secara menyeluruh sehingga mampu memberikan kepercayaan yang kuat akan kemampuan diri melakukan tindakan dalam mencapai berbagai tujuan hidup.

Kubravi, Shah \& Jan (2018) menjelaskan tentang kepercayaan diri sebagai sikap positif yang dimiliki individu sehingga memberikan kemampuan dalam diri untuk menerima atau menilai secara positif terhadap dirinya maupun lingkungan atau situasi yang dihadapi. Charness, Rustichini, \& Van de Ven (2018) menjelaskan tentang rasa percaya diri pada anak diibaratkan seperti tongkat ajaib yang mampu memberikan perubahan masa depan anak dan memberikan pengaruh di semua aspek kehidupan, seperti teman-teman yang dipilih, prestasi akademis di sekolah, pekerjaan yang akan diperoleh, dan lain sebagainya.

Berdasarkan beberapa pendapat yang diuraikan sebelumnya dapat disimpulkan bahwa kepercayaan diri merupakan kondisi mental atau psikologis individu yang mampu memberikan keyakinan dan kesadaran dalam jiwanya melalui penilaian sifat yang positif sehingga mampu memberikan kekuatan yang mendorongnya untuk memberikan kemampuan dalam diri untuk menerima dan menilai secara positif terhadap dirinya maupun lingkungan dan situasi yang dihadapi sehingga motivasi yang dimiliki dapat berkembang, sanggup bekerja keras dan belajar untuk maju, serta dipenuhi dengan keyakinan akan peran yang dijalaninya.

Hasil penelitian terdahulu yang dilakukan oleh Pangestu, Edwita, \& Bachtiar (2019) tentang pengaruh kepercayaan diri dan komunikasi interpersonal terhadap kemampuan berpikir kritis siswa SD menunjukkan bahwa kemampuan berpikir kritis siswa dipengaruhi langsung oleh kepercayaan diri; kemampuan berpikir kritis dipengaruhi oleh komunikasi interpersonal; dan komunikasi interpersonal dipengaruhi oleh kepercayaan diri siswa. Melalui kepercayaan diri yang dimiliki, siswa mampu mengoptimalkan perkembangan kemampuan berpikir kritisnya.

Kemampuan berpikir kritis erat kaitannya dengan motivasi belajar siswa. Siswa yang termotivasi dalam kegiatan pembelajaran akan menciptakan kondisi pembelajaran yang menyenangkan. Gairah dalam belajar juga akan tumbuh pada siswa yang termotivasi dalam belajar. Motivasi merupakan proses mendorong dan mempertahankan tujuan dengan mengarahkan perilaku (Schunk, 2012). Slavin (2011) menyatakan motivasi sebagai sesuatu yang menjadi alasan seorang individu bergerak, membuatnya tetap bergerak, dan menentukan kemana mencoba bergerak. Dari pendapat Slavin dapat kita kaji tentang motivasi sebagai sesuatu yang muncul dari dalam diri yang mendorongnya agar selalu belajar sehingga tercapai tujuan yang diharapkan.

Pendapat lain diungkapkan oleh Hanafiah \& Suhana (2012) tentang motivasi belajar sebagai energi, daya penggerak, atau alat yang membangun kesanggupan dan keinginan kuat yang muncul dari dalam diri 
1977 Pengaruh Kepercayaan Diri dan Motivasi Belajar terhadap Kemampuan Berpikir Kritis pada Siswa Sekolah Dasar - Siti Ambarwati, Suhartono, Nurhasanah

DOI: https://doi.org/10.31004/edukatif.v3i4.1047

untuk belajar secara inovatif, aktif, dan kreatif, serta menyenangkan untuk mewujudkan perubahan diri dari berbagai aspek baik dalam aspek pengetahuan, sikap, maupun perilaku. Pendapat dari Uno (2016) menyatakan bahwa siswa dengan motivasi belajar memiliki memiliki hasrat dan keinginan untuk berhasil dalam belajar sehingga muncul dorongan keinginan, semangat, dan kebutuhan dalam belajar yang didukung pula dengan adanya harapan dan cita-cita masa depan. Siswa yang tinggi motivasi belajarnya tentu memiliki cita-cita di masa depan yang akan diperjuangkan dengan sekuat tenaga dan kemampuan. Dengan demikian, dapat disimpulkan bahwa motivasi belajar sebagai bentuk perhatian siswa berupa kekuatan, pendorong, dan pembangun dari dalam diri untuk fokus pada tujuan belajar sehingga terjadi perubahan perilaku dalam aspek kognitif, afektif, dan psikomotor, aspek kognitif salah satunya berkaitan pada kemampuan berpikir kritis. Hal tersebut tentu akan berpengaruh pula pada keuletan mereka dalam belajar, tidak mudah berputus asa, dan senang memecahkan permasalahan. Apabila dalam diri mereka sudah ditumbuhkembangkan motivasi belajar akan memberikan kemudahan siswa dalam pengembangan kemampuan berpikir yang dimilikinya termasuk kemampuan dalam berpikir kritis.

Hasil penelitian yang dilakukan oleh Nugraha, Suyitno, \& Susilaningsih (2017) pada siswa kelas V SD menunjukkan bahwa motivasi belajar memberikan pengaruh terhadap kemampuan berpikir kritis dengan sangat kuat. Siswa yang tinggi motivasi belajarnya cenderung tinggi pula kemampuan berpikir kritis yang dimiliki. Berpikir kritis yang dimiliki siswa dipengaruhi tinggi rendahnya motivasi belajar. Siswa dengan motivasi belajar maupun kemampuan berpikir kritis yang tinggi akan tertarik untuk memecahkan soal, lebih menyukai tantangan, lebih ulet.

Hasil penelitian yang sejalan dengan pentingnya pengaruh kepercayaan diri dan motivasi belajar dilakukan oleh Wright dan Bar, Sartorelli, dan Swartz \& Parks yang menjelaskan cara yang dapat digunakan untuk meningkatkan kemampuan berpikir yaitu dengan meningkatkan keingintahuan siswa, kemampuan untuk menanya, mengamati model, dan diskusi yang kaya (Hassoubah, 2008). Kegiatan diskusi dan bertanya jawab tentu membutuhkan kepercayaan diri siswa yang baik. Kepercayaan diri dari siswa akan memberikan keyakinan dan dorongan dari diri untuk berani mengungkapkan pemikirannya, menanggapi pendapat siswa lain, sehingga tecipta motivasi belajar yang baik pula. Apabila kepercayaan diri dan motivasi belajar siswa mampu didorong dan ditumbuhkembangkan dengan baik maka akan membantu perkembangan kemampuan berpikirnnya.

Berdasarkan uraian yang telah dikemukakan sebelumnya dapat diketahui bahwa tujuan penelitian ini yaitu untuk menganalisis pengaruh antara kepercayaan diri dan motivasi belajar terhadap kemampuan berpikir kritis pada siswa kelas V SD se-Kecamatan Ambal.

\section{METODE PENELITIAN}

Penelitian ini adalah penelitian kuantitatif dengan metode ex post facto yang dianalisis dengan uji regresi linear berganda. Ada dua variabel bebas (independent variable) yaitu metode pembelajaran $\left(\mathrm{X}_{1}\right)$ dan motivasi belajar siswa $\left(\mathrm{X}_{2}\right)$ dalam penelitian ini. Sedangkan variabel terikatnya adalah kemampuan berpikir kritis siswa (Y). Populasi dalam penelitian ini adalah seluruh siswa Kelas V SD Negeri di Kecamatan Ambal, Kabupaten Kebumen. Sedangkan sampel penelitian diperoleh dengan cara simple random sampling yaitu 3 SD negeri dengan jumlah subjek penelitian sebanyak 95 siswa yang dilaksanakan pada bulan Agustus s.d. Oktober 2020.

Berikut desain penelitian yang menunjukkan hubungan antar variabel penelitian yang digambarkan pada Gambar 1. berikut: 
1978 Pengaruh Kepercayaan Diri dan Motivasi Belajar terhadap Kemampuan Berpikir Kritis pada Siswa Sekolah Dasar - Siti Ambarwati, Suhartono, Nurhasanah

DOI: https://doi.org/10.31004/edukatif.v3i4.1047

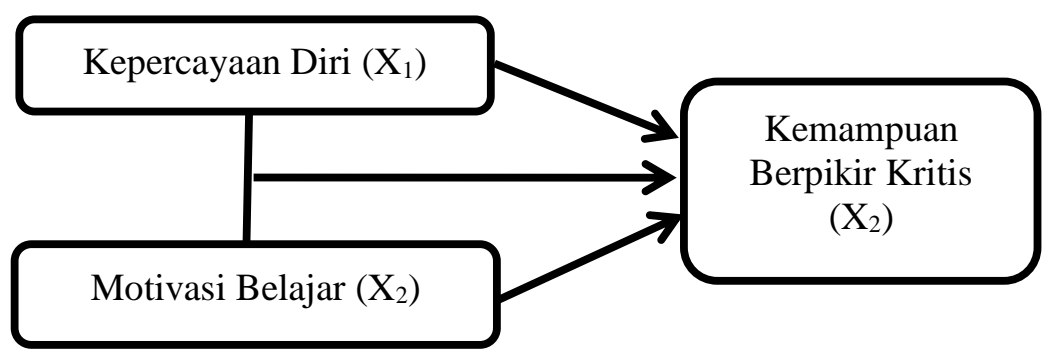

Gambar 1: Desain Penelitian

Instrumen yang digunakan dalam penelitian ini adalah instrumen tes (tes kemampuan berpikir kritis) dan instrumen angket (angket kepercayaan diri dan motivasi belajar) yang disusun berdasarkan kisi-kisi instrumen yang tekah disusun sebelumnya. Angket dikembangkan dengan skala Likert dengan menyajikan empat alternatif jawaban yang bersifat positif. Semakin tinggi kepercayaan diri dan motivasi belajar siswa dinyatakan dalam pernyataan positif dengan skor tertinggi adalah 4, sedangkan semakin rendah dinyatakan dengan pernyataan negatif skor tertinggi adalah 1 . Untuk tiap-tiap item soal dengan perincian sebagai berikut.

1) Selalu (SL) dengan nilai 4

2) Sering (SR) dengan nilai 3

3) Kadang-kadang (KK) dengan nilai 2

4) Tidak pernah (TP) dengan nilai 1.

Teknik analisis pengujian instrumen penelitian dilakukan pula dengan uji validitas dan uji reliabilitasnya. Instrumen diujicobakan setelah dianalisis isi oleh dua orang tim ahli judgement expert sebelum digunakan yang selanjutnya dihitung menggukan indeks $\mathrm{V}$ dari Aiken. Instrumen kemudian diujicobakan pada 2 SD negeri dengan 54 responden.

Instrumen kemampuan berpikir kritis yang digunakan dalam pengambilan data berupa soal essay dengan jawaban terbuka (open questions) yang memancing timbulnya ide atau gagasan dari siswa berjumlah 12 item soal. Kepercayaan diri dan motivasi belajar diukur dengan skor komulatif yang menunjukkan adanya kepercayaan diri dan motivasi belajar dalam diri siswa yang diperoleh melalui angket setelah siswa menjawab butir-butir pernyataan yang tersaji dalam instrumen angket berbentuk skala Likert. Instrumen kepercayaan diri terdiri dari 32 butir pernyataan dan motivasi belajar tersaji dalam 37 butir pernyataan. Reliabilitas tes kemampuan berpikir kritis adalah 0,727. Reliabilitas angket kepercayaan diri sebesar 0,763. Sedangkan reliabilitas angket motivasi belajar diperoleh sebesar 0,873 .

Teknik analisis data terdiri dari analisis deskriptif dan analisis statistik. Secara deskriptif, data dijabarkan berdasarkan rata-rata (mean), nilai tengah (median), nilai yang sering muncul (modus), standar deviasi (standar deviation/sd), variant, nilai maksimal, nilai minimal, range, dan sum. Analisis secara statistik uji linear regresi berganda melalui uji $\mathrm{t}$ dan uji $\mathrm{F}$ yang sebelumnya terlebih dahulu dilakukan uji asumsi klasik seperti uji normalitas, uji linieritas, uji multikolonieritas, dan uji heteroskedastisitas. Uji t dilakukan untuk menunjukkan seberapa jauh pengaruh yang nyata secara parsial antara kepercayaan diri terhadap kemampuan berpikir kritis siswa maupun pengaruh antara motivasi belajar terhadap kemampuan berpikir kritis siswa. Sedangkan uji $\mathrm{F}$ dilakukan untuk mengetahui apakah kepercayaan diri dan motivasi belajar berpengaruh secara bersama-sama terhadap kemampuan berpikir kritis siswa. Proses perhitungan data penelitian dilakukan dengan menggunakan SPSS 25.

Berdasarkan pemaparan yang telah diuraikan sebelumnya dengan faktor yang diduga memiliki pengaruh terhadap kemampuan berpikir kritis siswa kelas V SD, maka hipotesis yang diuji diuraikan sebagai berikut:

H1: Ada pengaruh kepercayaan diri terhadap kemampuan berpikir kritis pada siswa kelas V SD seKecamatan Ambal. 
1979 Pengaruh Kepercayaan Diri dan Motivasi Belajar terhadap Kemampuan Berpikir Kritis pada Siswa Sekolah Dasar - Siti Ambarwati, Suhartono, Nurhasanah

DOI: https://doi.org/10.31004/edukatif.v3i4.1047

H2: Ada pengaruh motivasi belajar terhadap kemampuan berpikir kritis pada siswa kelas V SD se-Kecamatan Ambal.

H3: Ada pengaruh kepercayaan diri dan motivasi belajar terhadap kemampuan berpikir kritis siswa kelas V SD se-Kecamatan Ambal

\section{HASIL DAN PEMBAHASAN PENELITIAN}

Jumlah sampel dalam penelitian ini adalah 3 SD negeri dengan jumlah siswa 95 siswa. Secara deskriptif , variabel terikatnya $(\mathrm{Y})$ adalah kemampuan berpikir kritis. Data kemampuan berpikir kritis diperoleh melalui tes essay dengan 12 pertanyaan. Selanjutnya yang menjadi variabel bebas $\left(\mathrm{X}_{1}\right)$ adalah kepercayaan diri. Data kepercayaan diri diperoleh malalui penyebaran angket berjumlah 32 butir pernyataan. Selain itu, variabel bebas lainnya $\left(\mathrm{X}_{2}\right)$ adalah motivasi belajar yang diperoleh dari angket dengan 37 butir pernyataan. Adapun ringkasan deskripsi hasil penelitian ditampilkan dalam Tabel 1 berikut:

Tabel 1 Ringkasan Hasil Perhitungan Statistik Deskriptif

\begin{tabular}{cccc}
\hline Data Statistik & $\begin{array}{c}\text { Kemampuan Berpikir } \\
\text { Kritis }\end{array}$ & Kepercayaan Diri & Motivasi Belajar \\
\hline Rerata & 36,19 & 101,37 & 110,43 \\
\hline Median & 36 & 103 & 109 \\
\hline Modus & 35 & 97 & 104 \\
\hline Simpangan Baku & 3,998 & 9,44 & 14,40 \\
\hline Skor Minimal & 28 & 77 & 141 \\
\hline Skor Maksimal & 44 & 118 & 14,401 \\
\hline Standar Deviasi & 3,998 & 9,317 & 207,376 \\
\hline Varians & 15,985 & 86,810 & \\
\hline
\end{tabular}

Sumber: Data primer yang diolah

Secara statistik, data hasil penelitian terlebih dahulu dilakukan uji asumsi klasiknya atau uji prasyarat analis data yaitu uji normalitas, uji linieritas, uji multikolonieritas, dan uji heteroskedastisitas. Uji normalitas data dilakukan untuk mengetahui apakah data setiap kelompok sampel berdistribusi normal dengan Kolomogorof-Smirnov melalui perolehan angka probabilitas atau Asymp. Sig. (2-tailed). dengan kriteria signifikasi $5 \%(0,05)$ yang menunjukkan data berdistribusi normal jika signifikasi data $\geq 0,05$, sedangkan signifikasi data $<0,05$ menunjukkan data tidak berdistribusi normal.

Tabel 2 Ringkasan Hasil Perhitungan Uji Normalitas Data

\begin{tabular}{lccl}
\hline \multicolumn{1}{c}{ Kelompok Data } & Kolmogorof-Smirnov $\boldsymbol{Z}$ & $\begin{array}{c}\text { Nilai Asymp. Sig. } \\
\text { (2-tailed) }\end{array}$ & Keputusan \\
\hline Kepercayaan diri & 0,085 & 0,200 & Berdistribusi Normal \\
\hline Motivasi Belajar & 0,071 & 0,200 & Berdistribusi Normal \\
\hline Kemampuan Berpikir Kritis & 0,085 & 0,085 & Berdistribusi Normal \\
\hline
\end{tabular}

Sumber: Data primer yang diolah

Berdasarkan Tabel 2 di atas terlihat bahwa seluruh sampel berdistribusi normal angka probabilitas atau Asymp. Sig. (2-tailed) $\geq 0,05$. dengan demikian seluruh sampel dalam penelitian ini berasal dari populasi yang berdistribusi normal.

Uji asumsi klasik berikutnya adalah uji linieritas untuk mengetahui hubungan antar variabel linier atau tidak dari hasil $F_{\text {hitung }}$ Deviation From Linearity. Kriteria pengujiannya jika $\mathrm{F}_{\text {hitung }}<\mathrm{F}_{\text {tabel}}$, maka kedua variabel berpola linier. Jika $F_{\text {hitung }}>F_{\text {tabel, }}$ maka kedua variabel memiliki pola yang tidak tidak linear. Hasil $F_{\text {tabel }} 3,10$, hasil perhitungan $F_{\text {hitung }}$ Deviation From Linearity antara kemampuan berpikir kritis dengan kepercayaan diri 
1980 Pengaruh Kepercayaan Diri dan Motivasi Belajar terhadap Kemampuan Berpikir Kritis pada Siswa Sekolah Dasar - Siti Ambarwati, Suhartono, Nurhasanah

DOI: https://doi.org/10.31004/edukatif.v3i4.1047

adalah 1,428. Selain itu antara kemampuan berpikir kritis dengan motivasi belajar menunjukkan hasil 0,786. Hasil tersebut menunjukkan hubungan yang linier antara kepercayaan diri dengan kemampuan berpikir kritis maupun motivasi belajar dengan kemampuan berpikir kritis.

Uji multikolonieritas dilakukan untuk menunjukkan adanya hubungan korelasi yang kuat dan linier antara variabel kepercayaan diri dan motivasi belajar terhadap variabel kemampuan berpikir kritis berdasarkan nilai Variance Inflation Faktor (VIF) dan nilai tolerance dari masing-masing variabel bebas terhadap variabel terikat. Hasil perhitungan nilai VIF adalah 2,292 dengan nilai toleransi 0,436. Dengan demikian diperoleh kesimpulan bahwa dalam model regresi tidak terjadi multikolonieritas.

Uji asumsi klasik yang terakhir adalah uji heteroskedastisitas yang akan menunjukkan varian variabel tidak sama untuk semua pengamatan. yang diperoleh pada kolom Unstrandardized Residual pada hasil SPSS. Model regresi dengan nilai Sig. lebih besar dari taraf signifikansi (sig. > 0,05) menunjukkan tidak adanya heteroskedastisitas. Hasil perhtungan diperoleh nilai Sig. kepercayaan diri 0,781 dan motivasi belajar 0, 943. Hasil tersebut menunjukkan bahwa model regresi ini terbebas dari heteroskedastisitas.

Setelah seluruh rangkaian uji asumsi klasik terpenuhi, data hasil penelitian kemudian diuji hipotesisnya melalui uji t dan uji F. Uji t dilakukan untuk membuktikan pengaruh kepercayaan diri terhadap kemampuan berpikir kritis dan membuktikan pengaruh motivasi belajar terhadap kemampuan berpikir kritis. Sedangkan uji F dilakukan untuk membuktikan pengaruh kepercayaan diri dan motivasi belajar secara bersama-sama terhadap kemampuan berpikir kritis.

\section{Pengaruh Kepercayaan Diri terhadap Kemampuan Berpikir Kritis}

Berdasarkan hasil uji $\mathbf{t}$ dengan kriteria pengujian hipotesis diterima jika apabila nilai signifikasi $\leq 0,05$ maka hipotesis diterima yang berarti ada pengaruh antara variabel bebas terhadap variabel terikat. Sedangkan hipotesis ditolak apabila nilai signifikansi $>0,05$. Hasil perhitungan diperoleh Sig. t $0,00<\alpha(0,05)$ dengan nilai $\mathbf{t}_{\text {tabel }}$ dari tabel distribusi $\mathbf{t}$ untuk $\alpha=0,05$ diperoleh hasil $\mathbf{t}_{\text {hitung }}=10,225$ sedangkan $\mathbf{t}_{\text {tabel }}$ diperoleh 1,9858 dengan taraf signifikansi 5\%. Dengan demikian, karena $\mathbf{t}_{\text {hitung }}>\mathbf{t}_{\text {tabel }}$ maka $\mathrm{H}_{01}$ ditolak dan terima $\mathrm{H}_{11}$ yang berarti ada pengaruh yang signifikan kepercayaan diri $\left(\mathrm{X}_{1}\right)$ terhadap kemampuan berpikir kritis $(\mathrm{Y})$. Besarnya kontribusi pengaruh yang signifikan kepercayaan diri terhadap kemampuan berpikir kritis adalah 47,10\%.

Hasil perhitungan menunjukkan bahwa seorang siswa dengan kepercayaan diri tinggi dalam diri akan membantu meningkatkan kemampuan berpikir kritis yang dimiliki sehingga kemampuan berpikir kritis siswa dipengaruhi secara signifikan oleh variabel kepercayaan diri. Siswa dengan kepercayaan diri yang tinggi, berpengaruh pula dengan tingginya kemampuan berpikir kritis yang dimiliki. Demikian pula siswa dengan kepercayaan diri yang rendah, memiliki kemampuan berpikir kritis yang rendah pula.

Seorang individu dengan kepercayaan diri tinggi akan mampu memberikan dorongan untuk dirinya agar tanggap dalam menghadapi persoalan secara positif, bertindak secara mandiri, termasuk berani dalam berpendapat (Lauster, 2005). Keberanian dalam menyampaikan pendapat akan berpengaruh dalam perkembangan kemampuan berpikir seorang individu dalam pengambilan keputusan. Hal tersebut mengandung maksud, kepercayaan diri mampu memberikan dorongan agar harapan dan cita-cita seseorang dapat terwujud karena keyakinan dalam pengambilan sebuah keputusan atau tindakan sangat dipengaruhi oleh kepercayaan diri yang dimiliki individu.

Kepercayaan diri mampu menyalurkan pikiran positif yang dapat memberdayakan dirinya dan memandang atau menilai secara positif baik tentang dirinya, lingkungan atau situasi yang dihadapi (Kubravi et al., 2018). Siswa dengan kepercayaan diri akan mampu memberikan keyakinan positif terhadap kemampuan yang dimiliki dengan menerima apa adanya, baik positif maupun negatif yang akan diperoleh melalui proses belajar yang menjadi modal dasar untuk mencapai kesuksesan di masa depan. Dengan demikian kelebihan yang dimiliki mampu dikembangkan secara optimal, termasuk kemampuan dalam mengambil keputusan dalam pemecahan masalah secara cermat dan mendalam untuk membuat keputusan tentang apa yang harus 
1981 Pengaruh Kepercayaan Diri dan Motivasi Belajar terhadap Kemampuan Berpikir Kritis pada Siswa Sekolah Dasar - Siti Ambarwati, Suhartono, Nurhasanah

DOI: https://doi.org/10.31004/edukatif.v3i4.1047

diyakini atau dilaksanakan yang berpengaruh terhadap masa depan individu. Pengambilan keputusan tentang apa yang harus diyakini atau dilaksanakan secara masuk akal dan reflektif sesuai dengan pendapat dari Ennis (dalam Fisher, 2008: 4) tentang berpikir kritis.

Hasil penelitian ini juga mendukung penelitian terdahulu yang dilakukan oleh Pangestu, Edwita \& Bachtiar (2019) yang menyatakan bahwa secara signifikan kepercayaan diri berpengaruh langsung terhadap kemampuan berpikir kritis siswa sekolah dasar. Melalui pengembangan kepercayaan diri siswa, kemampuan berpikir kritis dapat dikembangkan secara optimal sehingga siswa tumbuh menjadi pribadi yang percaya akan potensi yang dimiliki sehingga mampu mengoptimalkan kemampuan dalam dirinya yang berpengaruh terhadap masa depan.

\section{Pengaruh Motivasi Belajar terhadap Kemampuan Berpikir Kritis}

Hasil uji $\mathbf{t}$ dengan kriteria pengujian hipotesis diterima jika nilai signifikasi $\leq 0,05$ yang berarti variabelvariabel bebas berpengaruh secara simultan terhadap variabel terikat. Hasil Sig. t $0,00<\alpha(0,05)$. Berdasarkan perbandingan nilai $F_{\text {hitung }}$ dengan $F_{\text {tabel }}$, hipotesis akan diterima jika nilai $F_{\text {hitung }}>F_{\text {tabel. }}$ Nilai $t_{\text {tabel }}$ ditentukan dari tabel distribusi $\mathbf{t}$ untuk $\alpha=0,05$ diperoleh hasil $\mathbf{t}_{\text {hitung }}=7,252$ sedangkan $\mathbf{t}_{\text {tabel }}$ diperoleh 1,9858 dengan taraf signifikansi 5\%. Dengan demikian, karena $\mathbf{t}_{\text {hitung }}>\mathbf{t}_{\text {tabel }}$ maka $\mathrm{H}_{02}$ ditolak dan terima $\mathrm{H}_{12}$ yang berarti ada pengaruh yang signifikan kepercayaan diri $\left(\mathrm{X}_{1}\right)$ terhadap kemampuan berpikir kritis $(\mathrm{Y})$. Besarnya kontribusi pengaruh yang signifikan kepercayaan diri terhadap kemampuan berpikir kritis adalah 35,11\%.

Data tersebut menunjukkan jika seorang siswa dengan motivasi belajar yang tinggi dalam dirinya maka akan membantu meningkatkan kemampuan berpikir kritisnya sehingga variabel motivasi belajar memberikan pengaruh yang signifikan terhadap kemampuan berpikir kritis siswa. Siswa yang tinggi motivasi belajarnya, berpengaruh pula terhadap kemampuan berpikir kritis yang dimiliki. Demikian pula siswa dengan motivasi belajar yang rendah, memiliki kemampuan berpikir kritis yang rendah pula.

Hasil tersebut sesesuai dengan pendapat dari Dewey yang menyatakan bahwa berpikir kritis sebagai sikap aktif, gigih, melalui pertimbangan secara cermat yang menunjukkan keinginan atau motivasi dan semangat dalam menemukan jawaban atas permasalahan yang dihadapi (Surya, 2011). Pernyataan tersebut memberikan penjelasan bahwa siswa yang kuat motivasi belajarnya akan memberikan pengaruh pula terhadap kemampuan berpikir kritisnya karena motivasi belajar mampu memberikan dorongan yang kuat dalam diri yang akan memunculkan sikap gigih dan semangat dalam diri sehingga lebih cermat dalam menanggapi permasalahan yang dihadapi.

Pendapat dari Uno (2016) menyatakan bahwa siswa dengan motivasi belajar memiliki memiliki hasrat dan keinginan untuk berhasil dalam belajar sehingga muncul dorongan keinginan, semangat, dan kebutuhan dalam belajar yang didukung pula dengan adanya harapan dan cita-cita masa depan. Siswa yang tinggi motivasi belajarnya tentu memiliki cita-cita di masa depan yang akan diperjuangkan dengan sekuat tenaga dan kemampuan. Hal tersebut berarti ada dorongan, keyakinan, dan keinginan kuat yang ada dalam diri agar menjadi yang terbaik, mencapai apa yang diinginkan dan diharapkan, termasuk sebagai siswa untuk mendapatkan nilai bagus, bahkan keinginan menjadi juara kelas. Dengan demikian, siswa tersebut akan berusaha untuk menguasai materi pelajaran, tidak mudah menyerah, dan bersemangat dalam berlajar.

Hasil penelitian ini mendukung penelitian yang telah dilakukan oleh Nugraha, Suyitno, \& Susilaningsih (2017) pada siswa kelas V SD menunjukkan bahwa motivasi belajar memberikan pengaruh terhadap kemampuan berpikir kritis dengan sangat kuat. Siswa yang tinggi motivasi belajarnya cenderung tinggi pula kemampuan berpikir kritis yang dimiliki. Berpikir kritis yang dimiliki siswa dipengaruhi tinggi rendahnya motivasi belajar. Siswa dengan motivasi belajar maupun kemampuan berpikir kritis yang tinggi akan tertarik untuk memecahkan soal, lebih menyukai tantangan, lebih ulet. Hal tersebut senada dengan pendapat dari Uno (2016). 
1982 Pengaruh Kepercayaan Diri dan Motivasi Belajar terhadap Kemampuan Berpikir Kritis pada Siswa Sekolah Dasar - Siti Ambarwati, Suhartono, Nurhasanah

DOI: https://doi.org/10.31004/edukatif.v3i4.1047

Motivasi belajar menjadi sesuatu yang penting bagi siswa. Motivasi dapat memberikan kesadaran bagi siswa dalam kehidupannya, termasuk saat mengikuti kegiatan pembelajaran. Motivasi belajar yang baik akan mampu membentuk perilaku yang termotivasi, dengan adanya perilaku yang termotivasi diharapkan dapat menjadi sumber energi siswa untuk belajar lebih terarah dan dipertahankan hingga berkembang pemikiran mereka dalam belajar. Melalui motivasi yang ada dalam diri dan dari orang lain termasuk guru, siswa mampu diarahkan dan disadarkan tentang pentingnya proses belajar dalam kehidupan sehingga siswa tumbuh menjadi pribadi yang gigih dan tidak mudah menyerah dan berputus asa dalam mengerjakan tugas yang memberikan tantangan melalui pembelajaran yang dilakukan dengan menyenangkan, berpusat pada siswa, dan memberikan tantangan sehingga terpacu motivasi belajarnya. Apabila motivasi belajarnya sudah meningkat dan baik, maka dapat pula meningkatkan kemampuan berpikir kritisnya.

\section{Pengaruh Kepercayaan Diri dan Motivasi Belajar terhadap Kemampuan Berpikir Kritis}

Berdasarkan hasil uji $\mathrm{F}$ hipotesis dengan kriteria nilai signifikasi $\leq 0,05$ yang berarti kepercayaan diri dan motivasi belajar berpengaruh secara simultan terhadap kemampuan berpikir kritis. Hipotesis ditolak apabila menunjukkan nilai signifikansi $>0,05$. Selain itu juga menggunakan perbandingan nilai $F_{\text {hitung }}$ dengan $F_{\text {tabel. }}$ Hasil analisis menunjukkan nilai Sig. $0,00 \leq 0,05$. Selain itu Hasil uji F pada regresi ganda menunjukkan hasil $F_{\text {hitung }}=307,729$ dan $F_{\text {tabel }}=3,09$ dengan taraf signifikansi 5\% menunjukkan $F_{\text {hitung }}>F_{\text {tabel }}$. Berdasarkan hasil tersebut maka $\mathrm{H}_{03}$ ditolak dan terima $\mathrm{H}_{13}$ yang berarti ada pengaruh kepercayaan diri $\left(\mathrm{X}_{1}\right)$ dan motivasi belajar $\left(\mathrm{X}_{2}\right)$ terhadap kemampuan berpikir kritis $(\mathrm{Y})$ karena $\mathrm{F}_{\text {hitung }}>\mathrm{F}_{\text {tabel. }}$. Persamaan regresi ganda yang terbangun $\hat{Y}=-1,784+0,25 X_{1}+0,115 X_{2}$ dengan koefisien korelasi sebesar 0,933 . Koefisien korelasi yang positif mengandung arti bahwa kepercayaan diri dan motivasi belajar secara bersama-sama memiliki pengaruh positif terhadap kemampuan berpikir kritis. Besarnya kontribusi pengaruh yang signifikan kepercayaan diri dan motivasi belajar secara bersama sama terhadap kemampuan berpikir kritis adalah $82,21 \%$. Sedangkan faktor atau variabel lain yang tidak dibahas dalam penelitian menyumbang sebesar 17,79\%. Dengan demikian kepercayaan diri dan motivasi belajar siswa ditumbuhkembangkan dengan maksimal maka akan memberikan dampak yang mendukung pengembaangan kemampuan berpikir kritis siswa.

Beberapa hal memungkinkan memberikan pengaruh pada perkembangan kemampuan berpikir siswa. Melalui penciptaan suasana belajar yang menarik, diskusi yang kaya, mengungkapkan pendapat, meningkatkan keingintahuan siswa untuk menanya, kemampuan berpikir kritis dapat ditingkatkan. Hal tersebut sesuai dalam mendukung hasil penelitian yang dilakukan oleh Wright dan Bar, Sartorelli, dan Swartz \& Parks yang menjelaskan cara yang dapat digunakan untuk meningkatkan kemampuan berpikir dengan meningkatkan keingintahuan siswa, kemampuan untuk menanya, mengamati model, dan diskusi yang kaya (Hassoubah, 2008). Kegiatan diskusi dan bertanya jawab tentu membutuhkan kepercayaan diri siswa yang baik. Kepercayaan diri dari siswa akan memberikan keyakinan dan dorongan dari diri untuk berani mengungkapkan pemikirannya, menanggapi pendapat siswa lain, sehingga tecipta motivasi belajar yang baik pula. Apabila kepercayaan diri dan motivasi belajar siswa mampu didorong dan ditumbuhkembangkan dengan baik maka akan membantu perkembangan kemampuan berpikirnhya.

Hasil penelitian ini juga sejalan dengan pendapat dari Dewey tentang definisi berpikir kritis (critical thingking) sebagai sikap aktif, gigih, melalui pertimbangan yang cermat melalui berbagai sudut pandang yang mendukung dan membuat kesimpulan tentang keyakinan atau pengetahuan apapun yang diterima seorang individu (Surya, 2011). Dengan demikian berpikir kritis memerlukan sikap yang gigih, aktif dalam menyimpulkan atau membuat keputusan mengenai keyakinan dalam dirinya tentang pengetahuan yang diterima seorang individu termasuk siswa. Kegigihan dan keaktifan individu sangat dibutuhkan dalam perkembangan berpikir kritis. Kegigihan dan keaktifan dalam belajar merupakan salah satu ciri adanya motivasi belajar siswa (Hamzah Uno., 2016). Siswa yang aktif dan gigih akan memiliki dorongan keinginan, semangat, dan kebutuhan dalam belajar. Melalui dorongan dalam diri maupun lingkungan sangat berpengaruh 
1983 Pengaruh Kepercayaan Diri dan Motivasi Belajar terhadap Kemampuan Berpikir Kritis pada Siswa Sekolah Dasar - Siti Ambarwati, Suhartono, Nurhasanah

DOI: https://doi.org/10.31004/edukatif.v3i4.1047

terhadap tumbuhnya motivasi dalam belajar (Yusuf, 2010). Keyakinan dalam diri akan memunculkan kepercayaan diri tentang apa yang dimiliki, apa yang telah diperoleh sehingga bila di dukung dengan motivasi belajar akan mampu menumbuhkembangkan kemampuan berpikir kritis siswa. Kegiatan pembelajaran di sekolah agar tumbuh motivasi, dapat didorong melalui pemberian pujian, hadiah, maupun pengakuan dari orang lain baik guru maupun siswa lain (Sardiman, 2011).

Seperti pendapat dari Charness, Rustichini, \& Ven de Ven (2018) tentang pentingnya rasa percaya diri pada anak diibaratkan seperti tongkat ajaib yang mampu memberikan perubahan masa depan anak dan memberikan pengaruh di semua aspek kehidupan. Melalui kepercayaan diri dan motivasi belajar yang muncul karena kayakinan dari dalam diri maupun dari orang lain, siswa akan tumbuh menjadi pribadi yang senantiasa positif pemikirannya, mampu memotivasi dirinya, ulet dalam menghadapi permasalahan sehingga memiliki kemampuan dalam mengambil keputusan pemecahan masalah secara cermat dan mendalam untuk memutuskan suatu hal yang diyakini atau dilakukan yang berpengaruh terhadap masa depan. Pengambilan keputusan secara cermat sesuai dengan keyakinan dalam diri atau apa yang dilakukan secara masuk akal dan reflektif sesuai dengan pendapat dari Ennis tentang berpikir kritis (Fisher, 2011). Dengan demikian kepercayaan diri dan motivasi belajar berpengaruh terhadap kemampuan berpikir kritis siswa kelas V SD SeKecamatan Ambal.

\section{KESIMPULAN}

Berdasarkan pemaparan hasil analisis yang telah dilakukan, diperoleh kesimpulan sebagai berikut: 1) Ada pengaruh yang signifikan antara kepercayaan diri terhadap kemampuan berpikir kritis siswa kelas V SD se-Kecamatan Ambal. 2) Ada pengaruh yang signifikan antara motivasi belajar terhadap kemampuan berpikir kritis siswa kelas V SD se-Kecamatan Ambal. 3) Ada pengaruh yang signifikan antara kepercayaan diri dan motivasi belajar terhadap kemampuan berpikir kritiskelas V SD se-Kecamatan Ambal.

\section{UCAPAN TERIMA KASIH}

Terima kasih saya ucapakan kepada keluarga, dosen pembimbing yang telah memberikan ilmu yang sangat bermanfaat demi penyelesaian TAPM ini, rekan-rekan mahasiswa Prodi Magister Pendidikan Dasar Universitas Terbuka, seluruh dosen dan staff UPBJJ UT Purwokerto yang telah membantu peneliti dalam menyelesaikan penelitian ini.

\section{DAFTAR PUSTAKA}

Assaly, I. R., \& Smadi, O. M. (2015). Using Bloom's Taxonomy To Evaluate The Cognitive Levels Of Master Class Textbook's Questions. English Language Teaching, 8(5), 100-110.

Bowell, T., \& Kemp, G. (2005). Critical Thinking: A Concise Guide. Routledge.

Charness, G., Rustichini, A., \& Van De Ven, J. (2018). Self-Confidence And Strategic Behavior. Experimental Economics, 21(1), 72-98.

Fachrurazi. (2011). Penerapan Pembelajaran Berbasis Masalah Untuk Meningkatkan Kemampuan Berpikir Kritis Dan Komunikasi Matematis Siswa Sekolah Dasar. Jurnal Penelitian Pendidikan UPI, Edisi Khus(1), 76-89. Http://Jurnal.Upi.Edu/Penelitian-Pendidikan/View/637/

Fatimah, E. (2006). Psikologi Perkembangan (Perkembangan Peserta Didik). Pustaka Setia.

Fisher, A. (2011). Critical Thinking: An Introduction. Cambridge University Press.

Hakim, T. (2005). Mengisi Rasa Tidak Percaya Diri. Purwa Suara. 
1984 Pengaruh Kepercayaan Diri dan Motivasi Belajar terhadap Kemampuan Berpikir Kritis pada Siswa Sekolah Dasar - Siti Ambarwati, Suhartono, Nurhasanah

DOI: https://doi.org/10.31004/edukatif.v3i4.1047

Hamzah Uno., B. (2016). Tugas Guru Dalam Pembelajaran. Jakarta: Bumi Aksara.

Hanafiah, N., \& Suhana, C. (2012). Konsep Strategi Pembelajaran Cet Ke-3. Refika Aditama.

Hassoubah, Z. I. (2008). Mengasah Pikiran Kreatif Dan Kritis. Nuansa.

Kubravi, S. U., Shah, S. O., \& Jan, K. (2018). Digital Story Telling: The Impact On Student Academic Achievement, Critical Thinking And Learning Motivation. International Journal Of Research In Engineering, Science And Management, 1(12), 787-791.

Lauster, P. (2005). Tes Kepribadian (Terjemahan: DH Gulo). Bumi Aksara.

Nizam. (2016). Ringkasan Hasil-Hasil Asesmen Belajar Dari Hasil UN, PISA, TIMSS, INAP. Puspendik.

Nugraha, A. J., Suyitno, H., \& Susilaningsih, E. (2017). Analisis Kemampuan Berpikir Kritis Ditinjau Dari Keterampilan Proses Sains Dan Motivasi Belajar Melalui Model Pbl. Journal Of Primary Education, $6(1), 35-43$.

Pangestu, P. S., Edwita, E., \& Bachtiar, I. G. (2019). Pengaruh Kepercayaan Diri Dan Komunikasi Interpersonal Terhadap Kemampuan Berpikir Kritis Siswa Sekolah Dasar. Taman Cendekia: Jurnal Pendidikan Ke-SD-An, 3(2), 381-387.

Sardiman, A. M. (2011). Interaksi Dan Motivasi Belajar Mengajar. Rajawali Press.

Schunk, D. H. (2012). Learning Theories An Educational Perspective Sixth Edition. Pearson.

Setiawan, P. (2014). Siapa Takut Tampil Percaya Diri. Parasmu.

Slavin, R. E. (2011). Psikologi Pendidikan Teori Dan Praktik. Indeks.

Suciati, Wardani, I. G. A. K., Winataputra, U. S., \& Mustafa, D. (2014). Integrasi Teori Dan Praktek Pembelajaran. In Paradigma Belajar Dan Pembelajaran. Universitas Terbuka.

Sugiyarti, L., Arif, A., \& Mursalin. (2018). Pembelajaran Abad 21 Di SD. Prosiding Seminar Dan Diskusi Nasional Pendidikan Dasar, 439-444.

Surya, M. (2011). Strategi Kognitif Dan Proses Pembelajaran. Alfabeta.

Yusuf, S. (2010). Psikologi Perkembangan Anak Dan Remaja. PT. Remaja Rosakarya. 